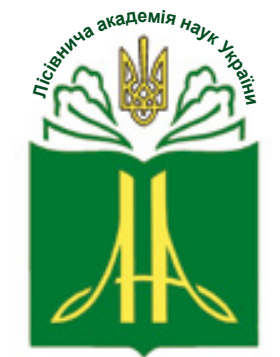

Forestry Academy of Sciences of Ukraine
Наукові праці Лісівничої академії наук України Proceedings of the Forestry Academy of Sciences of Ukraine http://fasu.nltu.edu.ua

https://doi.org/10.15421/411933

Article received 2019.05.22

Article accepted 2019.12.26
ISSN 1991-606X print

ISSN 2616-5015 online

@ $\triangle$ Correspondence author

Roman Yatsyk

yatsykr@ukr.net
Grushevskogo str., 31, Ivano-Frankivsk, 76018, Ukraine

\title{
Селекційно-насінницькі аспекти збереження та відтворення популяцій Pinus cembra L. в Українських Карпатах
}

\author{
Р.М. Яцик ${ }^{1}$, М. М. Сіщук², Ю.І. Гайда ${ }^{3}$ Ю.Д. Кацуляк ${ }^{4}$
}

Подано результати лісівничо-селекиійних досліджень сосни кедрової європейської (Pinus сетьra L.) на чотирьох пробних ділянках, площею від 0,6 до 1,0 га, закладених у деревостанах ичього деревного виду на гіпсометричних рівнях 1150-1380 м над рівнем моря в Горганах. Визначено критерії відбору кандидатів у плюсові дерева для подальшого розвитку плюсової селекції та плантаційного клонового насінництва.

Виявлено домінування в деревостанах дерев з овальними та округлими кронами, яких тут понад $56 \%$. $3 a$ результатами емпіричних і статистичних досліджень встановлено, щзо під час відбору й атестації плюсових дерев сосни кедрової європейської доиільно орієнтуватися на біотипи з округлими кронами.

Виявлено взаємозв'язок між типами та забарвленням ритидома $i$ селекиійними категоріями дерев. Дерева вищих селекиійних категорій характеризуються лускатоподібним ритидомом (кандидати в плюсові I кат. - 100\%, плюсові II кат. - 61\%) коричневого кольору (кандидати в плюсові I кат. - 62\%, плюсові II кат. $-61 \%$ ).

Для збереження і відтворення популяцій сосни кедрової європейської варто провести відбір й атестацію плюсових дерев, здійснити їх вегетативне розмноження, отримати клони для подальшого розвитку насінницттва на основі клонових насінних плантацій. Доцільно також запровадити заходи зі збереження й ефективного використання урожаю «горішків» сосни кедрової європейської, вирошування доброякісного садивного матеріалу і створення біотично стійких лісових культур. Деревостанам з ознаками кедрових пралісів доцільно надати статус об' єктів цінного генетичного та природно-заповідного фонду.

Ключові слова: лісовирощування; селекційна структура; формове різноманіття; зразок плюсового дерева; клонове плантаційне насінництво.

\footnotetext{
Яцик Роман Михайлович - член-кореспондент Лісівничої академії наук України, кандидат сільськогосподарських наук, старший науковий співробітник, доцент, провідний науковий співробітник лабораторії лісовідновлення і селекції. Український науково-дослідний інститут гірського лісівництва ім. П.С. Пастернака, вул. Грушевського, 31, м. Івано-Франківськ, 76018, Україна. Тел.: +38-050-274-36-49. E-mail: yatsykr@ukr.net ORCID 0000-0002-4008-0215.

2 Сішук Мар'яна Миколаївна - молодший науковий співробітник лабораторії лісовідновлення і селекції. Український науково-дослідний інститут гірського лісівництва ім. П.С. Пастернака, вул. Грушевського, 31, м. Івано-Франківськ, 76018, Україна. Тел.:+38-096-178-81-02. E-mail: maryanasishuk@gmail.com ORCID 0000-0002-3141-0737.

3 Гайда Юрій Іванович - академік Лісівничої академії наук України, доктор сільськогосподарських наук, професор кафедри економіки біоресурсів і природокористування. Тернопільський національний економічний університет, вул. Львівська, 11, м. Тернопіль, 46009, Україна. Тел.: +38-097-228-35-34. E-mail: haydshn@ua.fm ORCID 0000-0001-6019-9654.

4 Каиуляк Юрій Дмитрович - член-кореспондент Лісівничої академії наук України, кандидат сільськогосподарських наук, старший науковий співробітник, завідувач лабораторії лісовідновлення і селекції. Український науково-дослідний інститут гірського лісівництва ім. П. С. Пастернака, вул. Грушевськаого, 31, м. Івано-Франківськ, 76018, Україна. Тел.: +38-096-279-83-66. E-mail: girlis@ukr.net ORCID 0000-00024152-6741.
} 
Вступ. Pinus cembra L. в Карпатах - післяльодовиковий релікт і цінна лісотвірна порода. Займаючи кам'янисті розсипища, їі деревостани відіграють велику грунтотвірну, грунтозахисну і водорегулятивну роль (Molotkov, 1957, Smahlyuk, 1972, Sirenko, 2008). Дотепер у природних карпатських лісах цей деревний вид зберігся переважно у важкодоступних екстремальних лісорослинних умовах Горган (зрідка - Чорногори) на високогірних каменистих схилах на висотах 1100-1500 м н.р.м. (понад 80\% - 12501450 м) у вологих і сирих суборах, де утворює мішані зі смерекою європейською деревостани, а також заходить у борові зарості гірської сосни.

Деякі дерева і куртини 3 участю «карпатського кедра» трапляються також у діапазоні висот 8001600 м над рівнем моря. Тут цей вид росте хоч i повільно, але за життєвою формою є деревом. Філогенетично сосна кедрова європейська є одним із найстарших серед аборигенних лісотвірних видів i $€$ нащадком живих свідків геологічного минулого, які пережили катаклізми льодовикового періоду, суттєве потепління клімату та нищівну господарську діяльність у післявоєнний період через надзвичайну цінність іiі деревини. Припускають, що більшим довгожителем в Карпатах може бути хіба що тільки тис ягідний (Kolishchuk,1968, Smahlyuk, 1972, Stoyko, 1988, Sirenko, 2007).

Загальна площа деревостанів за участю Pinus cembra L. становить близько 6,3 тис. га, а редукована - тільки близько 250 га (Smahlyuk, 1972). Майже $92 \%$ їх ростуть на Івано-Франківщині і найбільше поширені на територіях Осмолодського, Солотвинського, Надвірнянського лісгоспів та Природного заповідника «Горгани» (рис. 1). Найвідомішими місцезнаходженнями цього виду на Закарпатті $є$ урочища Кедрин Брустурянського лісгоспу, заказники Горган і Тавпіширка, Брадульський, а на Буковині - урочище Сарат Путильського лісгоспу.

Різновікові кедрово-смерекові ліси (вік деяких особин сосни кедрової сягає понад 500 років), порівняно 3 чистими одновіковими смерічниками, більш стійкі, а запас стовбурової деревини в них інколи може сягати навіть $400 \mathrm{~m}^{3} \cdot \mathrm{ra}^{-1}$. Домішка сосни кедрової у складі високогірних лісів рідко перевищує 5 од., а в найпоширеніших характерних кедрово-смерекових деревостанах - 1-3. Чисті куртини кедра трапляються вкрай рідко. Більшість їх виділено у заказники, заповідні урочища, пам'ятки природи.

Формування сосни кедрової європейської як самостійного виду дослідники пов'язують 3 можливим розривом під час льодовикового періоду єдиного колись євроазійського ареалу сосни кедрової сибірської, або розселенням тієї сосни із сибірського ареалу в Європу і наступною ізоляцією ії тут. Адже ареал виду складається з двох областей. Більша частина розповсюджена від південних районів Франції до східних районів Альп, на півночі доходить до Женевського озера. Друга, менша область, розміщена у Високих Татрах і Карпатах (Stoyko, 1988, Sirenko, 2005, Krunutskyj \& Tretyak, 2003).

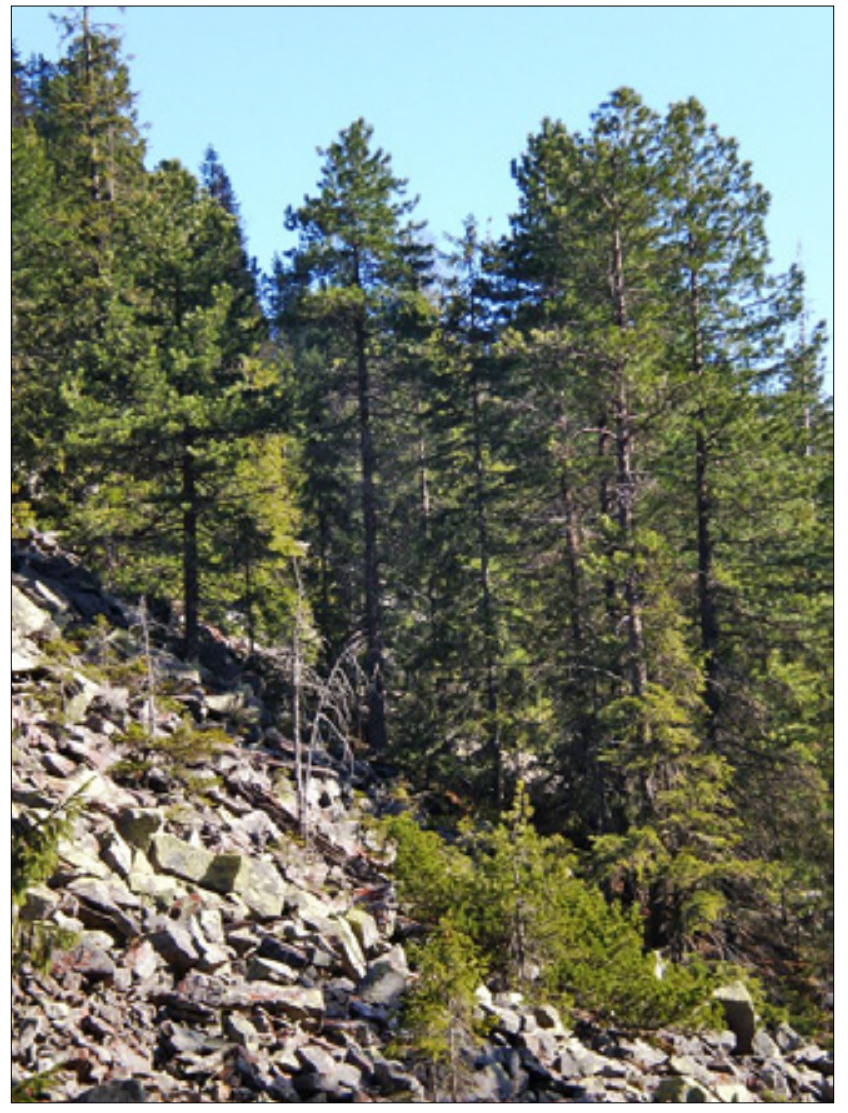

Рис. 1. Угруповання сосни кедрової європейської у природному заповіднику «Горгани»

Ймовірно, що в холодні фази плейстоцену і в ранньому голоцені сосна кедрова європейська, разом із соснами звичайною і гірською, були поширені тут на великих площах. Поступово вони були витіснені у більш високі теперішні місцезнаходження через відчутне потепління і значне зниження вологості клімату. Якщо в Альпах виділено лісорослинний пояс кедрових лісів завширшки 250-950 м, то в нашому регіоні вони поширені розірваною смугою у верхів'ях річок Свічі, Лімниці, Бистриць Солотвинської і Надвірнянської, Пруту і Чорного Черемошу (Smahlyuk, 1972).

3 огляду на подальше швидке потепління клімату та зростання сухості повітря, що призводить до пониження грунтових вод, нині у системі заходів, спрямованих на збереження, відновлення і розширення лісів з участю сосни кедрової європейської, важливе місце належить штучному відновленню цього виду на основі селекції. Для цього потрібно використовувати методи як плюсової селекції і створення клонових насінних плантацій, так і популяційної селекції й використання кращих деревостанів, передусім лісових генетичних резерватів.

Зважаючи на наведене вище, на цей час надзвичайно актуальним завданням карпатських лісівників $є$ створення стійких мішаних високогірних насаджень 3 перевагою сосни кедрової європейської 
на генетико-селекційній основі, якими можливо хоч частково замінити чисті всихаючі деревостани ялини європейської.

Об'єкти та методика досліджень. Об' $\epsilon$ кm дослідження - відтворення і розширення популяцій сосни кедрової європейської в Українських Карпатах. Предмет дослідження - лісівничо-селекційна характеристика деревостанів сосни кедрової європейської. Мета досліджень - визначити й обгрунтувати критерії відбору плюсових дерев сосни кедрової європейської для створення іiї постійної лісонасінної бази на генетико-селекційній основі.

Дослідження проводили на чотирьох постійних пробних ділянках (ППД) у Горганах. ППД № 1 та ППД № 2 закладено у природному заповіднику «Горгани», (Горганське ПОНДВ, урочище «Джурджі»), на схилі гори Полєнський площею 0,6 та 1,0 га, відповідно. ППД № 3 та ППД № 4 закладено в Гутянському лісництві ДП «Солотвинське лісове господарство» також площею 0,6 і 1,0 га, відповідно.

У цих умовах на висоті 1150-1380 м н.р.м. сосна кедрова європейська росте в борах і суборах разом із смерекою європейською та сосною гірською (іноді - березою повислою) на слабо розвинених щебенисто-каменистих i торф'яно-підзолистих грунтах потужністю переважно до 30 см (подекуди на кам'янистих розсипищах). Незважаючи на сильну кам'янистість, у грунтах чітко виражені ознаки підзолоутворення, чому сприяють лісова підстилка, мохи та інші види надгрунтового покриву.

Несприятливі кліматичні й едафічні умови обмежують асортимент деревно-кущових видів, здатних спільно з кедром утворювати деревостани. Підріст, зазвичай, тут відсутній, або ж трапляються поодиноко смерека i кедр. Максимальна його кількість, яку ми облікували, становить не більше 200 шт. га $^{-1}$. Десятирічний підріст досягає висоти 50 см. Дуже рідко трапляється також вегетативне відновлення окремих гілок кедра, які звисають 3 низькоопущених крон дерев, торкаються щілин між камінням, підстилки і грунту і поступово укорінюються.

У підліску трапляються горобина звичайна, верба козяча, ялівець сибірський і крушина ламка, а в живому надгрунтовому вкритті - чорниця, брусниця, види плаунів, зелених мохів, ожика лісова, плеврозій Шребера, багно звичайне, орляк (табл. 1). Навіть незначне руйнування підстилки і грунту завдають непоправної екологічної шкоди, повертаючи грунтотвірні процеси на багато років назад.

Розмір ППД визначали із розрахунку охоплення нею не менше 100 дерев сосни кедрової європейської, що було пов'язано з великими труднощами, адже знайти такі площі із значною перевагою кедра виявилося досить складно. Деревостани описували за стандартними лісівничими параметрами, проводили повний перелік дерев. Середню висоту визначали шляхом вимірювання 15-20 дерев пропорційно до їх кількості в кожній ступені товщини.

Для досягнення мети роботи ми застосовували методику вивчення формової і селекційної структури насаджень, яка розроблена в галузевих лісових науково-дослідних інститутах - УкрНДІЛГА (Molotkov, Patlay \& Davydova, 1989, Volosyanchuk, Los \& Torosova, 2003) та УкрНДІгірліс (Yatsyk, Vorobchuk \& Parpan, 2006, Hayda, Popadynets \& Yatsyk, 2008, Hayda, 2012).

Усі дерева розподіляли на чотири селекційні категорії - кандидати у плюсові дерева I категоpiï, кандидати у плюсові дерева II категорії (синонім - кращі з нормальних (Veresin, Efimov \& Arefev, 1985), нормальні і мінусові. Морфологічні та інші якісні характеристики (форма крони, тип і забарвлення кори тощо) визначали згідно з розробленими нами класифікаціями. Тип і забарвлення кори визначали на висоті грудей (1,3 м) стовбурів дерев 3 верхнього боку схилу. Статистичне опрацювання емпіричних даних здійснювали 3 використанням алгоритму розрахунку коефіцієнта взаємної спряженості К. Пірсона і методу аналізу відповідності (Lakin, 1990, Halafjan, 2008).

Таблиця 1

\section{Лісівнича характеристика деревостанів сосни кедрової свропейської} на постійних пробних ділянках

\begin{tabular}{|c|c|c|c|c|c|c|}
\hline $\begin{array}{c}\text { № } \\
\text { ППД }\end{array}$ & $\begin{array}{l}\text { BHPM, } \\
\text { м }\end{array}$ & $\begin{array}{c}\text { Експозиція, } \\
\text { стрімкість схилу }\end{array}$ & $\begin{array}{l}\text { Індекс } \\
\text { типу лісу }\end{array}$ & Підріст & Підлісок & ЖНП \\
\hline 1 & 1150 & ПД: $10-12^{0}$ & $\mathrm{~B}_{3}-\mathrm{KCM}$ & відсутній & $\begin{array}{c}\text { поодиноко горобина } \\
\text { звичайна, верба козяча, } \\
\text { ялівець сибірський } \\
\text { крушина ламка }\end{array}$ & $\begin{array}{c}\text { брусниця, плауни баранець } \\
\text { і булавоподібний, сфагнум, } \\
\text { плеврозій Шребера }\end{array}$ \\
\hline 2 & $1250-1300$ & ПД: $15-20^{0}$ & $\mathrm{~B}_{3}-\mathrm{KCM}$ & те саме & відсутній & $\begin{array}{c}\text { чорниця, брусниця, зелені } \\
\text { мохи, орляк }\end{array}$ \\
\hline 3 & $1250-1300$ & ПД: 20-250 & $\mathrm{A}_{3}$-смК & те саме & $\begin{array}{c}\text { поодиноко горобина } \\
\text { звичайна, верба козяча, } \\
\text { ялівець сибірський }\end{array}$ & $\begin{array}{c}\text { чорниця, брусниця, зелені } \\
\text { мохи, сфагнум, ожика лісова, } \\
\text { багно звичайне }\end{array}$ \\
\hline 4 & $1350-1380$ & ПД: 20-250 & $\mathrm{B}_{3}-\kappa \mathrm{CM}$ & те саме & $\begin{array}{c}\text { поодиноко горобина } \\
\text { звичайна }\end{array}$ & $\begin{array}{c}\text { брусниця, чорниця, плауни } \\
\text { альпійський, баранець і } \\
\text { булавоподібний }\end{array}$ \\
\hline
\end{tabular}


Результати досліджень. За результатами обстеження досліджуваних деревостанів виявлено, що частка участі сосни кедрової європейської в них становить 40-80\%. За віком дерева різняться від 130 до 310 років. Повнота деревостанів - 0,5-0,7, бонітет $-\mathrm{IV}-\mathrm{V}$, середня висота - 13-20 м, середній діаметр - 23-36 см, запас - 120-250 м ${ }^{3} \mathrm{ra}^{-1}$. Співвідношення між висотою і діаметром дерев, які можуть слугувати показником адаптивності, особли- во індикатором стійкості до кліматичних чинників та екологічної валентності, становить 0,45-0,65 (табл. 2.) Таке співвідношення 3 віком дещо підвищується. Дослідники стверджують, що це свідчить про підвищену конкуренцію дерев (Matveeva, Bratilova \& Butorova, 2008). Відносно широкий діапазон росту зумовлюється також суттєвою різницею тривалості вегетаційного періоду, яка становить від 85 до 105 діб.

Таблиия 2

Таксаційні показники деревостанів сосни кедрової свропейської на ППД

\begin{tabular}{ccccccccc}
\hline № ППД & Склад насадження & Вік, років & Повнота & Бонітет & $\mathrm{H}_{\mathrm{cp}}, \mathrm{M}$ & $\mathrm{D}_{\mathrm{cp}}, \mathrm{cm}$ & $\mathrm{H} / \mathrm{D}$ & $\mathrm{M}, \mathrm{M}^{3} \mathrm{ra}^{-1}$ \\
\hline 1 & 8Ск.с.2См + Сг & $140-160$ & 0,5 & $\mathrm{IV}$ & 20 & 32 & 0,62 & 200 \\
2 & 7Ск.с.3См + Сг & $180-200$ & 0,7 & $\mathrm{~V}$ & 18 & 36 & 0,50 & 250 \\
3 & 8Ск.є.2См & $160-200$ & 0,6 & $\mathrm{~V}$ & 13 & 29 & 0,45 & 120 \\
4 & 6См4Ск.є.+ Бп & $130-310$ & 0,5 & $\mathrm{~V}$ & 15 & 34 & 0,65 & 140 \\
\hline
\end{tabular}

Примітка: Ск.є. - сосна кедрова європейська; См - смерека європейська; Сг - сосна гірська; Бп - береза повисла.

У деревостанах виявлено 10,1\% кандидатів у плюсові дерева I і II категорій (відповідно 3,2 та $6,9 \%$ ), нормальних $-57,5 \%$, мінусових $-32,4 \%$.

Довготривала історія широкого діапазону змін природних умов сприяла тому, що в сосни кедрової європейської сформувалися своєрідні біотипи, здатні рости у формі дерева вище верхньої межі розповсюдження лісу, на кам'янистих розсипищах. Ї̈ї дерева характеризуються різноманітними формами крон. За цим показником ми об'єднали ïx у чотири основних групи: із колоноподібними, конусоподібними, округлими й овальними кронами (табл. 3). У деревостанах домінують дерева 3 овальними й округлими кронами, яких є понад $56 \%$ (рис. 2). Представництво дерев кожної з груп є досить близьким і різниться від 20,7 до 30,6\%.

Близько $70 \%$ дерев 3 колоноподібними, конусоподібними та округлими кронами віднесено до нормальних. Така сама їх кількість з овальними кронами $є$ мінусовими. Найменше мінусових дерев спостережено серед біотипів із округлими кронами $(10,6 \%)$, натомість їх найбільше серед кандидатів у плюсові (18,3\%). Кількість придатних для збору насіння дерев серед них (нормальні і плюсові) становить близько $90 \%$ (див. табл. 3 ). Очевидно, що під час відбору й атестації плюсових дерев для розвитку плюсової селекції і плантаційного насінництва сосни кедрової європейської потрібно передусім орієнтуватися на біотипи 3 округлими кронами.

Для статистичної оцінки ступеня взаємозв'язку між селекційною категорією та формою крон дерев розрахували коефіцієнт взаємної спряженості Пірсона. Його значення $(\mathrm{C}=0,493)$ свідчить про наявність помірного зв'язку між цими якісними показниками дерев сосни кедрової європейської.

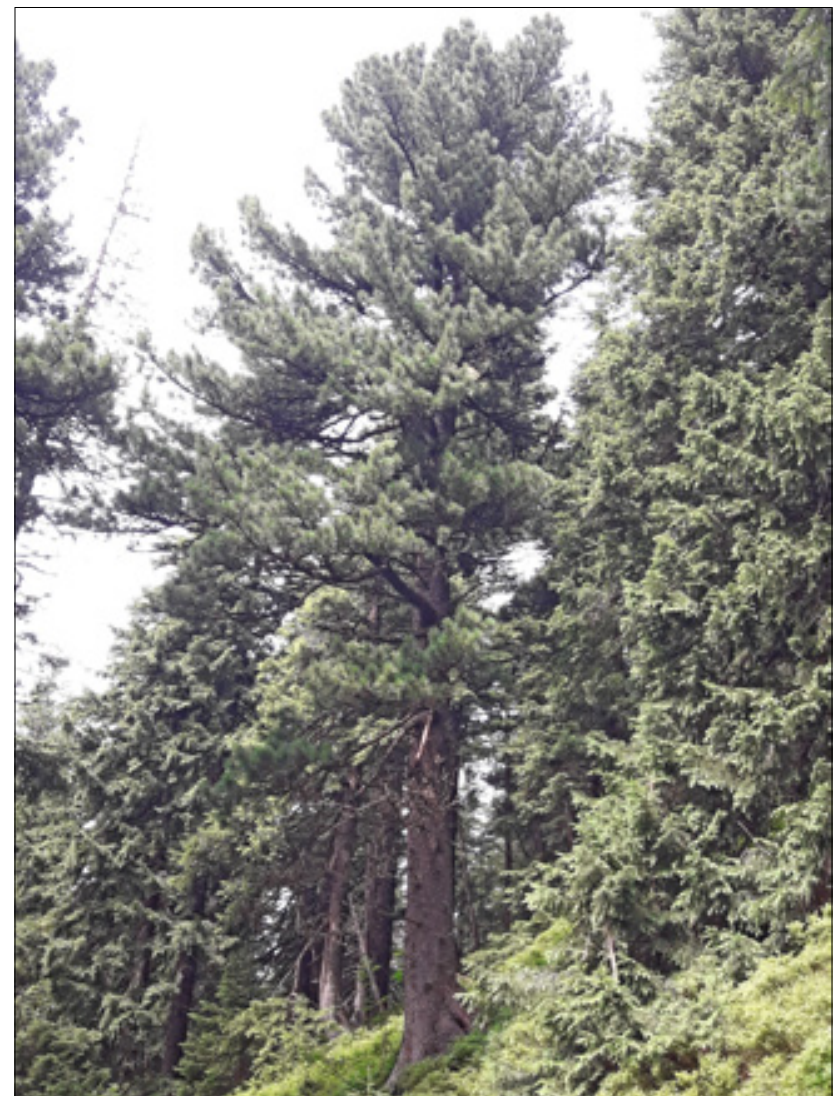

Рис. 2. Біотип сосни кедрової європейської з овальною кроною

Аналіз двовходової таблиці (див. табл. 3) методом аналізу відповідності (Correspondence analysis) також статистично підтверджує наявність залежності між формами крон дерев і їх селекційними категоріями $\left(\chi^{2}=129,9, \chi_{\text {st }}^{2}(0,001)=27,88, \mathrm{p}=0,000\right)$. Як видно на рис. 3 , де у форматі 2D відображено 
ординацію рядків і колонок проаналізованих даних двовходової таблиці, гострі кути, які утворюють вектори, що з'єднують центр ваги і точки Plus1, Plus2, Okrug, свідчать про наявність позитивної кореляції між цими якісними показниками дерев сосни кедрової європейської. Це підтверджує рані- ше зроблене припущення, що для плюсових дерев обох категорій більш характерною $є$ округла форма крони. Близька ординація точок Minus i Oval i, відповідно, дуже гострий кут між ними ілюструє досить високу кореляцію між стовпцем - мінусові дерева та рядком - овальна форма крони.

Таблиия 3

\section{Розподіл дерев сосни кедрової свропейської за формами крон у взаємозв'язку із селекційними категоріями}

\begin{tabular}{|c|c|c|c|c|c|c|c|c|c|c|}
\hline \multirow{3}{*}{ Форма крон } & \multirow{2}{*}{\multicolumn{2}{|c|}{$\begin{array}{l}\text { Кількість } \\
\text { дерев }\end{array}$}} & \multicolumn{8}{|c|}{ В т.ч. за селекційними категоріями } \\
\hline & & & \multicolumn{2}{|c|}{$\begin{array}{c}\text { кандидати в } \\
\text { плюсові I кат. }\end{array}$} & \multicolumn{2}{|c|}{$\begin{array}{c}\text { кандидати в } \\
\text { плюсові II кат. }\end{array}$} & \multicolumn{2}{|c|}{ нормальні } & \multicolumn{2}{|c|}{ мінусові } \\
\hline & шт. & $\%$ & шт. & $\%$ & шт. & $\%$ & шт. & $\%$ & шт. & $\%$ \\
\hline Колоноподібні & 93 & 23,0 & 3 & 3,2 & 9 & 9,7 & 65 & 69,9 & 16 & 17,2 \\
\hline Конусоподібні & 84 & 20,7 & 4 & 4,8 & 6 & 7,1 & 58 & 69,0 & 16 & 19,1 \\
\hline Округлі & 104 & 25,7 & 6 & 5,8 & 13 & 12,5 & 74 & 71,1 & 11 & 10,6 \\
\hline Овальні & 124 & 30,6 & - & - & - & - & 36 & 29,0 & 88 & 71,0 \\
\hline Усього & 405 & 100 & 13 & 3,2 & 28 & 6,9 & 233 & 57,5 & 131 & 32,4 \\
\hline
\end{tabular}

Впевнено стверджувати, що форми крони зумовлені лише генетичними чинниками, не доводиться, тому що більшість кедрових деревостанів ростуть в екстремальних умовах і в розрідженому стані. Але незважаючи на це, із практичного погляду їх варто враховувати під час селекційної інвентаризації дерев сосни кедрової європейської. У процесі дослідження виділено форми сосни кедрової європейської з лускатоподібним, пластинкоподібним, повздовжньо-тріщинуватим і гладким ритидомом коричневого, сірого і коричнювато-сірого забарвлення (табл. 4).

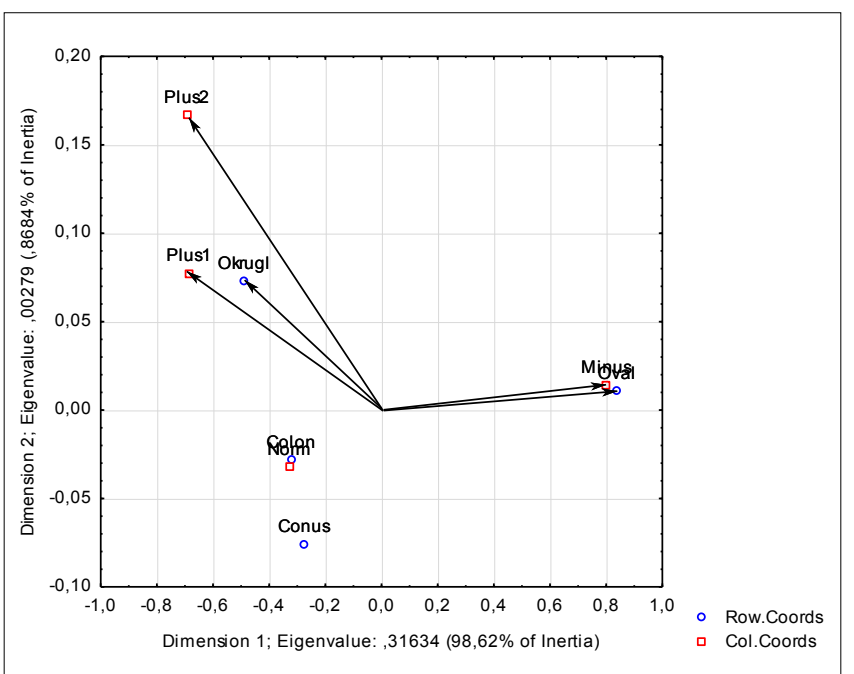

Рис. 3. 2D-графік координат рядків (різновидів форм крони) і колонок (селекційних категорій), розрахованих методом аналізу відповідності

Переважають дерева 3 лускатоподібним ритидомом, яких виявлено в деревостанах $63,2 \%$,
3 пластинкоподібним - $25,4 \%$, повздовжньотріщинуватим $-8,7 \%$, а 3 гладким ритидомом тільки $2,7 \%$. Майже половина дерев мають коричневе забарвлення ритидома $(46,7 \%)$, менша кількість $(37 \%)$ - сіре і значно менше $(16,3 \%)-$ коричнювато-сіре.

Виявлено певний взаємозв'язок між типами та забарвленням ритидома 3 одного боку і селекційними категоріями дерев, 3 іншого. Найкращі дерева трапляються 3 лускатоподібним ритидомом (плюсові I кат. - 100\%, плюсові II кат. - 61\%) коричневого кольору (плюсові I кат. - 62\%, плюсові II кат. - 61\%). Мінусовим деревам властивий пластинкоподібний ритидом сірого забарвлення, а повздовжньо-тріщинуватий і гладкий ритидом різного кольору - для дерев нормальної селекційної категорії.

Аналіз показав, що кандидати в плюсові дерева сосни кедрової європейської перевищують середні показники деревостанів за висотою на 10-50, за діаметром - на 10-70\%. Довжина крони в них зазвичай становить $30-70 \%$, а безсучкової зони - тільки 20-30\% від загальної висоти дерева. У Карпатському регіоні офіційно атестовано лише 19 плюсових дерев у Закарпатті (Брустурянське лісове господарство, Кедринське лісництво).

Найпоширенішими вадами сосни кедрової у досліджуваних деревостанах $\epsilon$ дуже погана очищуваність стовбурів від сучків, що $є$ іiі біологічною особливістю, а також кривизна стовбурів та їх збіжистість, багатоверхівковість, суховерхівковість і наявність пасинків. Більшість вад зумовлені негативною дією екстремальних умов навколишнього середовища і значним віком дерев. 
Розподіл дерев сосни кедрової свропейської за типом і забарвленням ритидома у взаємозв'язку зі селекційними категоріями

\begin{tabular}{|c|c|c|c|c|c|c|c|c|c|c|}
\hline \multirow{3}{*}{ Тип ритидома } & \multicolumn{4}{|c|}{ Кількість дерев } & \multicolumn{6}{|c|}{ В т.ч. за селекційними категоріями } \\
\hline & \multirow{2}{*}{ шт. } & \multirow[t]{2}{*}{$\%$} & \multicolumn{2}{|c|}{$\begin{array}{c}\text { кандидати в } \\
\text { плюсові I кат. }\end{array}$} & \multicolumn{2}{|c|}{$\begin{array}{c}\text { кандидати в } \\
\text { плюсові II кат. }\end{array}$} & \multicolumn{2}{|c|}{ нормальні } & \multicolumn{2}{|c|}{ мінусові } \\
\hline & & & шт. & $\%$ & шт. & $\%$ & шт. & $\%$ & шт. & $\%$ \\
\hline \multicolumn{11}{|c|}{ Коричневого забарвлення } \\
\hline Лускатоподібні & 130 & 32,1 & 8 & 6,1 & 11 & 8,5 & 89 & 68,5 & 22 & 16,9 \\
\hline Пластинкоподібні & 47 & 11,6 & - & - & 5 & 10,6 & 22 & 46,8 & 20 & 42,6 \\
\hline Повздовжньо-тріщинуваті & 10 & 2,5 & - & - & 1 & 10,0 & 5 & 50,0 & 4 & 40,0 \\
\hline Гладкі & 2 & 0,5 & - & - & - & - & 2 & 100 & - & - \\
\hline Разом & 189 & 46,7 & 8 & & 17 & & 118 & & 46 & \\
\hline \multicolumn{11}{|c|}{ Сірого забарвлення } \\
\hline Лускатоподібні & 90 & 22,2 & 3 & 3,3 & 3 & 3,3 & 52 & 57,8 & 32 & 35,6 \\
\hline Пластинкоподібні & 41 & 10,1 & - & - & - & - & 12 & 29,3 & 29 & 70,7 \\
\hline Повздовжньо-тріщинуваті & 19 & 4,7 & - & - & 2 & 10,5 & 14 & 73,7 & 3 & 15,8 \\
\hline Разом & 150 & 37,0 & 3 & & 5 & & 78 & & 64 & \\
\hline \multicolumn{11}{|c|}{ Коричновато-сірого забарвлення } \\
\hline Лускатоподібні & 36 & 8,9 & 2 & 5,6 & 3 & 8,3 & 21 & 58,3 & 10 & 27,8 \\
\hline Пластинкоподібні & 15 & 3,7 & - & - & 1 & 6,6 & 7 & 46,7 & 7 & 46,7 \\
\hline Повздовжньо-тріщинуваті & 6 & 1,5 & - & - & - & - & 3 & 50,0 & 3 & 50,0 \\
\hline Гладкі & 9 & 2,2 & - & - & 2 & 22,2 & 6 & 66,7 & 1 & 11,1 \\
\hline Разом & 66 & 16,3 & 2 & & 6 & & 37 & & 21 & \\
\hline Усього & 405 & 100 & 13 & 3,2 & 28 & 6,9 & 233 & 57,5 & 131 & 32,4 \\
\hline
\end{tabular}

Незважаючи на порівняно високу стійкість до несприятливих кліматичних й едафічних умов, сосні кедровій європейській істотно загрожують шкідники і хвороби, які пошкоджують шишки, горішки, підріст, стовбури та гілля дерев. Саджанці сосни кедрової європейської та іiї культури масово пошкоджує попелиця, уражають шютте, опеньок, особливо після 10-річного періоду росту.

Значну увагу приділено збереженню цього деревного виду на популяційному рівні, шляхом виділення лісових генетичних резерватів (ЛГР). У зв'язку із відсутністю великих масивів чистих кедрачів, до ЛГР віднесено кедрово-ялинові деревостани різного складу і структури на території ІваноФранківської області. Тут атестовано чотири ЛГР сосни кедрової європейської. Два 3 них - у лісовому фонді Бистрицького л-ва ДП «Осмолодське ЛГ» площею 38,0 га та Мшанського л-ва цього ж лісгоспу площею 263,0 га. Ще два ЛГР площею близько 300 га функціонують на території природного заповідника «Горгани». Крім цього, в генетичному резерваті площею 93,3 га, який відібрано у держлісфонді Гутянського л-ва ДП «Солотвинське ЛГ», представлено два види - смереку європейську і сосну кедрову європейську, тобто він $є$ полівидовим.

Початок генеративного періоду в окремо ростучих дерев кедра настає, в середньому, у 40, а в деревостанах - у 60 років. Репродуктивна здатність утримується аж до 300-річного віку. Шишки достигають на другий рік після «цвітіння». Періодичність насіннєношення становить близько 8-ми років. Smahlyuk (1972) зазначав, що на 1 га редукованої площі утворюється в середньому 760 кг шишок, 3 яких можна добути близько 180 кг «горішків». Але здійснити це можна лише теоретично, адже урожай масово, або ж практично увесь пошкоджують птахи. Тому ми рекомендуємо збирати шишки ще у восковій стиглості наприкінці серпня, витримувати їх у провітрюваному приміщенні впродовж 1-2 тижнів для дозрівання.

Узагальнення наукового і виробничого досвіду свідчить про високу ефективність як осіннього, так і весняного посівів горішків за умов надійного захисту їх від пошкоджень гризунами, птахами тощо. Хоч для весняного висіву насіння зазвичай традиційно стратифікують впродовж шести місяців, ми пропонуємо скоротити цей термін у 5-6 разів. Для цього застосовують метод так званих «шокових» температур, коли ящики 3 горішками та вологим піском кожен тиждень, почергово, поміщають то в холодні умови $\left(0 \ldots+5^{\circ} \mathrm{C}\right)$, то в теплі $\left(+20-25^{\circ} \mathrm{C}\right)$ до моменту появи проростків.

Посів насіння належить здійснити у розширені борозенки, які розміщують через 30 см, на глиби- 
ну 2,0-2,5 см, 80-100 «горішків» на 1 м посівного рядка. Садіння лісових культур у високогір'ї рекомендуємо проводити наприкінці травня - червні 4-річними сіянцями, або 5-6-річними саджанцями (кращий варіант) групами або кулісами.

Отримані результати спрямовані на збереження генофонду сосни кедрової європейської, удосконалення іiі селекції і насінництва. Адже змодельований зразок плюсового дерева можна використати в подальшому для відбору й атестації найкращих дерев цього виду та розвитку на їх основі плюсової селекції і плантаційного (особливо клонового) насінництва, а ЛГР - як популяційна модель насаджень майбутнього.

У Карпатському регіоні проходять багаторічне випробування також різні види інтродукованих кедрових сосен: сибірська, корейська, кедровий стелюх. Вони представлені у єдиних в Україні географічних культурах і в багатьох дендропарках, зокрема, в державних дендрологічних парках «Високогірний» $\mathrm{i}$ «Діброва». Найкраще адаптувалася в умовах регіону сосна кедрова корейська, яка 3 віком лише нарощує темп росту як у передгір'ї та низькогір'ї, так і в Карпатському високогір'ї. У такому широкому висотному діапазоні вона проявила себе як відносно швидкоросла порода порівняно 3 іншими інтродукованими кедровими соснами і $\epsilon$ стійкою до несприятливих кліматичних та едафічних умов, хвороб і шкідників. Порівняно рано вступає у генеративну фазу. Науковці вивели сорт «Сосна кедрова корейська Богородчанська».

Висновки. Проведені дослідження дали змогу змоделювати зразок плюсового дерева сосни кедрової європейської у гірських деревостанах Карпат. Це біотипи віком 140-180 років з округлою кроною, лускатоподібним ритидомом коричневого кольору, який переважає середні показники деревостанів за висотою і діаметром не менше ніж на $10 \%$. За довжиною крона займає $30-70 \%$, а безсучкова зона 20-30\% від загальної висоти дерева. Із вад у таких дерев допускається лише деяка сучкуватість (біологічна особливість цього виду), незначна кривизна (до $5 \%$ ) і помірна збіжистість стовбура.

Запропоновано способи отримання високоякісного насіння сосни кедрової європейської на генетико-селекційній основі: закладка клонових насінних плантацій та штучних постійних лісонасінних ділянок із селекційного садивного матеріалу (плантаційного типу) методом попереднього відбору кращих екземплярів у розсадниках (на другий рік вирощування), шкілці (на четвертий рік) та у висадженому насадженні (на шостий рік вирощування); регулярна заготівля шишок, які досягли воскової стиглості (переважно наприкінці серпня) у кращих популяціях (не менше ніж із 50 дерев); пришвидшені методи стратифікації насіння для весняного висіву (для кращого збереження «горішків» від гризунів) із застосуванням «шокових» температур, чергуючи високі $\left(+20 \ldots+25^{\circ}\right)$ та низькі $\left(0 \ldots+5^{0}\right)$ температури кожні 6-8 днів; удо- сконалена технологія й агротехніка вирощування якісного садивного матеріалу та лісових культур.

Наявні на сьогодні методи охорони, відтворення і розширення площ лісів сосни кедрової європейської не є достатніми. Щоб унеможливити скорочення площ деревостанів, пропонуємо створити картотеку лісів за участю сосни кедрової європейської; пришвидшити організаційну роботу, виділити, взяти під охорону і оформити залишки кедрових лісів у нові об'єкти природно-заповідного та цінного генетичного фонду (особливо лісові генетичні резервати) і праліси з урахуванням особливостей місцезростань й еколого-біологічних властивостей деревного виду.

Необхідно повсюдно здійснювати захист урожаю сосни кедрової європейської, а також молодняків і культур від пошкоджень, шкідників і хвороб. Також потрібно застосовувати методи збереження горішків від гризунів під час осіннього висіву. Вважаємо доцільним здійснювати лісорозведення сосни кедрової європейської на безлісих площах над сучасною верхньою межею лісу.

\section{References}

Hayda, Yu. I., Popadynets, I.M., Yatsyk, R.M., Parpan V.I., Humenyuk I. R, Kukharskyj T. V. ... Trentovskyj, V.V. (2008). Forest genetic resources and their conservation in the Ternopil region. Ternopil: Textbooks and manuals (in Ukrainian).

Hayda, Yu. I. (2012). Forestry and ecological basis for the conservation and sustainable use of forest genetic resources of the Western region of Ukraine (Abstract of doctoral dissertation, Ukrainian National Forestry University, Lviv, Ukraine). Available at: http:// dspace.tneu.edu.ua/jspui/handle/316497/1618 (in Ukrainian).

Halafjan, A.A. (2008). STATISTICA 6. Statistical data analysis. Textbook. Moskow, Binom-Press Ltd (in Russian).

Kolishchuk, V.H. (1968). Classification of life forms of procumbent woody plants. Ukrainian Botanical Journal, 25 (3), 59-66 (in Ukrainian).

Krynytskyy, H. T., \& Tretyak, P.R. (2003). The state of forests of the Ukrainian Carpathians, environmental problems and prospects. Environmental problems of the Carpathian region. Proceedings of the Shevchenko Scientific Society: Environmental Digest., XII, 54-65 (in Ukrainian).

Lakin, G.F. (1990). Biomentria. Moskow: Graduate School (in Russian).

Matveeva, R.N., Bratilova, N.P., \& Butorova, O.F. (2008). Useful properties and methods of reproduction of Siberian cedar. Krasnoyarsk: SibGU (in Russian).

Molotkov, P. I. (1957). Relics of cedar in Transcarpathia. Nature, 1 (in Ukrainian).

Molotkov, P. I., Patlay, I. M. \& Davydova, N. I. (1989). Seed production of forest species. Kyiv: Harvest (in Ukrainian). 
Sirenko, O.H. (2008). Alpine stone pine (Pinus cembra L.) in Ukraine: chorology, population structure and protection. Abstract of the candidate of biological sciences: speciality 03.00.05. Botany. Kyiv, Ukraine. (in Ukrainian).

Sirenko, O.H. (2005). Distribution and regression changes in the area of Alpine stone pine (Pinus cembra L.) in the Ukrainian Carpathians. Plant introduction, 1, 11-16 (in Ukrainian).

Sirenko, O.H. (2007). Ecological features of stands with the participation of Alpine stone pine (Pinus cembra L.) in the Ukrainian Carpathians. Plant introduction, 4, 64-71 (in Ukrainian).

Smahlyuk, K. K. (1972). Aboriginal coniferous forest producers. Uzhhorod: Carpathians (in Ukrainian).

Stoyko, S.M. (1988). Conservation of the Ukrainian Carpathians and adjacent territories. Ukrainian Carpathians. Nature, 2, 64-93 (in Ukrainian).

Veresin, M.M., Efimov, Yu. P., \& Arefiev, Yu. A. (1985). Handbook of forest breeding seed production. Moscow: Agropromizdat (in Russian).

Volosyanchuk, R., Los, S., Torosova, L., Kuznecova, T., Tereshchenko, L., Neyko, I., \& Grygoryeva, V. (2003). Methodological approaches to the estimation of gene pool conservation in situ units of the broadleaves tree species and their actual conditions in the Left-bank forest steppe of Ukraine. Forestry and forest melioration, 104, 50-57 (in Ukrainian).

Yatsyk, R.M., Vorobchuk, V.D., Parpan, V.I., Hayda, Yu. I., Stupar V.I., \& Kashpor, V. M. (2008). Genetic and selection and seed-growing objects in the forests of Bukovyna. Ternopil: Textbooks and manuals (in Ukrainian).

\section{Селекционно-семеноводческие аспекты сохранения и воспроизводства популяций Pinus cembra L. в Украинских Карпатах}

\author{
Р.М. Яцык', М.Н. Сищук ${ }^{2}$, Ю.И. Гайда ${ }^{3}$, \\ Ю.Д. Кацуляк ${ }^{4}$
}

Представлены результаты лесоводственноселекционных исследований сосны кедровой европейской (Pinus cembra L.) на четырех пробных участках, площадью от 0,6 до 1,0 га, заложенных в древостоях на высотах 1150-1380 м над уровнем моря в Горганах.

В процессе изучения лесоводственно-таксационных показателей и селекционно-формовой структуры древостоев сосны кедровой европейской определены критерии отбора кандидатов в плюсовые деревья с целью дальнейшего развития плюсовой селекции и плантационного клонового семеноводства исследуемого реликтового вида.

В древостоях отмечено доминирование деревьев с овальными и округлыми кронами, которых здесь насчитывается более $56 \%$. Определено, что во вре- мя отбора и аттестации плюсовых деревьев сосны кедровой европейской необходимо ориентироваться на биотипы с округлыми кронами.

Наблюдается определенная связь между типами и цветом ритидома 3 одной стороны, и селекционными категориями деревьев, с другой. Наилучшие деревья встречаются с чешуйчатым ритидомом (кандидаты в плюсовые I категории $100 \%$, в плюсовые II категории - $61 \%$ ) коричневого цвета (кандидаты в плюсовые I категории - $62 \%$, в плюсовые II категории - $61 \%$ ).

Уделено особое внимание сохранению данного вида на популяционном уровне путем выделения лесных генетических резерватов (ЛГР). В связи с отсутствием больших массивов чистых кедрачей в ЛГР отобрали четыре кедрово-еловые древостои разного состава и структуры. Два из них произрастают в лесах гослесфонда и два - на территории природного заповедника «Горганы».

Исследования дали возможность создать модель плюсового дерева сосны кедровой европейской в горных древостоях Карпат. Также предложены способы получения местных семян путем создания клоновых семенных плантаций, закладки постоянных лесосеменных участков из специально отобранного селекционного материала, ускоренные методы стратификации орешков, усовершенствованная технология и агротехника выращивания качественного посадочного материала и лесных культур. Это даст возможность расширить популяции ценного реликта, занесенного в Красную книгу Украины.

Анализ методов охраны, восстановления и расширения лесов сосны кедровой европейской

Яиььк Роман Михайлович - член-корреспондент Лесной академии наук Украины, кандидат сельскохозяйственных наук, старший научный сотрудник, доцент, ведущий научный сотрудник лаборатории лесовосстановления и селекции. Украинский научно-исследовательский институт горного лесоводства им. П.С. Пастернака, ул. Грушевского, 31, г. Ивано-Франковск, 76018, Украина. Тел.: +38-050-274-36-49. E-mail: yatsykr@ukr.net ORCID 0000-0002-4008-0215.

Сищук Марьяна Николаевна - младший научный сотрудник лаборатории лесовосстановления и селекции. Украинский научно-исследовательский институт горного лесоводства им. П.С. Пастернака, ул. Грушевского, 31, г. Ивано-Франковск, 76018, Украина. Тел.: +38-096-178-81-02. E-mail: maryanasishuk@gmail.com ORCID 0000-0002-3141-0737.

Гайда Юрий Иванович - действительный член Лесной академии наук Украины, доктор сельскохозяйственных наук, профессор кафедры экономики биоресурсов и природопользования. Тернопольский национальный экономический университет, ул. Львовская, 11, г. Тернополь, 46009 Украина. Тел.: +38-097-228-35-34. E-mail: haydshn@ua.fm ORCID 0000-00016019-9654

4 Каиуляк Юрий Дмитриевич - член-корреспондент Лесной академии наук Украины, кандидат сельскохозяйственных наук, старший научный сотрудник, заведующий лабораторией лесовосстановления и селекции. Украинский научно-исследовательский институт горного лесоводства им. П. С. Пастернака, ул. Грушевского, 31, г. Ивано-Франковск, 76018, Украина. Тел.: +38-096-279-83-66. E-mail: girlis@ukr.net ORCID 0000-0002-4152-6741. 
показал, что их нельзя считать достаточными. Поэтому следует создать картотеку лесных древостоев с ее участием, ускорить выделение их в новые объекты природно-заповедного и ценного генетического фонда с учетом эколого-биологических и лесоводственных особенностей вида.

Актуальна также защита урожая сосны кедровой европейской, ее посевов и лесных культур от повреждений, вредителей и болезней. Особенно следует учесть и трудности в создании насаждений данного вида в высокогорье, выше верхней границы леса на щебенисто-каменистой почве.

Ключевые слова: лесовыращивание; селекционная структура; формовое разнообразие; образец плюсового дерева; клоновое плантационное семеноводство.

\section{Breeding and seed production aspects of conservation and reproduction of Austrian stone pine (Pinus cembra L.) populations in the Ukrainian Carpathians}

\author{
R. Yatsyk ${ }^{1}$, M. Sishchuk², Yu. Hayda ${ }^{3}$, \\ Yu. Katsulyak ${ }^{4}$
}

The results of forestry and selection studies of Alpine stone pine (Pinus cembra L.) are presented in four test plots of 0.6 to 1.0 ha, planted in stands with its predominance at hypsometric levels of 1150-1380 m above sea level in Gorgany.

In the process of studying forest biometry indicators and the selection and form structure of Alpine stone pine stands, criteria for selecting plants for plus trees were determined with the aim of further development

Roman Yatsyk - Corresponding Member of the Forestry Academy of Sciences of Ukraine, Ph.D. in Agricultural Sciences, Senior researcher, Associate Professor, Leading researcher laboratory of forest planting and tree breeding of the Ukrainian Research Institute for Mountain Forestry after P. S. Pasternak, Grushevskyy str., 31, Ivano-Frankivsk, 76018, Ukraine. Tel.: +38-050-274-3649. E-mail: yatsykr@ukr.net ORCID 0000-0002-4008-0215.

Maryana Sishchuk - junior researcher laboratory of forest planting and tree breeding of the Ukrainian Research Institute for Mountain Forestry after P.S. Pasternak, Grushevskyy str., 31, IvanoFrankivsk, 76018, Ukraine. Tel.: +38-096-178-81-02. E-mail: maryanasishuk@gmail.com ORCID 0000-0002-3141-0737.

Yuriy Hayda - Full Member of the Forestry Academy of Sciences of Ukraine, Doctor of Agricultural Sciences, Professor department economical of life and environmental sciences. Ternopil National Ecologycal University, Lviv str., 11, Ternopil, 46009, Ukraine. Tel.: +38-097-228-35-34. E-mail: haydshn@ua.fm ORCID 0000-00016019-9654.

Yuriy Katsulyak - Corresponding Member of the Forestry Academy of Sciences of Ukraine, Ph.D. in Agricultural Sciences, Senior researcher, Head of laboratory of forest planting and tree breeding of the Ukrainian Research Institute for Mountain Forestry after P. S. Pasternak, Grushevskyy str., 31, Ivano-Frankivsk, 76018 Ukraine. Tel.: +38-096-279-83-66. E-mail: girlis@ukr.net ORCID $0000-0002-4152-6741$ of plus selection and clonal seed plantation of this relict species.

The dominance of trees with oval-shaped and rounded crowns, which are more than $56 \%$, is noted in stands. It was determined that during the selection and certification of plus trees of Alpine stone pine, one should focus on biotypes with rounded crowns.

A close correlation was found between the types and coloration of rhytidome on the one hand and tree selection categories, on the other. The best trees are found to have scaly-like rhytidome (plants for plus trees 1st Category - $100 \%$, for plus trees 2nd Category $-61 \%$ ) brown (plants for plus trees 1 st Category $-62 \%$, for plus trees 2nd Category $-61 \%$ ).

Attention is paid to the preservation of this species at the population level - by selecting forest genetic reserves (FGR). Due to the lack of large arrays of pure dwarf pines, four cedar/fir stands of different composition and structure were selected in the FGR. Two of them are in the forests of the State Forest Fund and two are on the territory of the Gorgany nature reserve.

The studies have allowed to develop a sample of a plus tree of Alpine stone pine in the mountain stands of the Carpathians. We also proposed methods for producing local seeds by creating clonal seed plantations, laying permanent forest seed plots from specially selected breeding material, accelerated methods of stratification of nuts, advanced technology and agricultural techniques for growing high-quality planting material and forest crops.

An analysis of the methods of protecting, restoring and expanding Alpine stone pine forests has shown that they cannot be considered sufficient. Therefore, it is necessary to create a card catalogue of forest stands with its participation, accelerate their allocation to new objects of the nature reserve and valuable genetic fund, taking into account the ecological, biological and forest features of the species.

The protection of the Alpine stone pine crop, its planting material and forest species from damage, pests and diseases remains relevant. It should be especially taken into account the difficulties in creating plantings of this species in the highlands, above the upper border of the forest line on gravelly soils.

It should be noted that abovementioned negative climate changes are most evident in the Carpathian highlands, where there is a massive drying of spruce forests, a decrease in their biological stability, and an increase in the area of damaged stands by diseases and pests. Therefore, forest management in this region is becoming increasingly costly and unpredictable. One of the main tasks in this case is to increase the forest areas and increase forest sustainability, that possible by forming high-quality mixed forests with the participation and Swiss stone pine predominance.

Key words: forest planting; breeding structure; diversity form; plus tree sample; clone seed production area. 